\title{
TINGKAT TUTUR BAHASA JAWA DALAM FILM KARTINI
}

\author{
Novia Ayu Rizky ${ }^{1}$, dan Dwi Puspitorini ${ }^{2}$ \\ Fakultas Ilmu Budaya Universitas Indonesia \\ Email:novia.ayu51@ui.ac.id, dwi.puspitorini@ui.ac.id
}

\begin{abstract}
Abstrak
Penelitian ini membahas tingkat tutur bahasa Jawa dengan pendekatan struktural dan sosiolinguistik.Masyarakat Jawa pada abad 19 yang digambarkan dalam film Kartini,yaitu masyarakat Jawa yangmenghormatiseseorang keturunan bangsawan. Hal tersebut terlihat dalam penggunaan tingkat tutur bahasa Jawa Ngoko dan Kramaketika penutur bertutur dengan mitra tutur yang bergelar bangsawan. Penelitian dilakukan untuk menjawab pertanyaan bagaimana cara pandang penutur terhadap mitra tutur di dalam masyarakat Jawa. Pendekatan struktural digunakan untuk menentukan bentuk tingkat tutur. Pendekatan sosiolingistik dilakukan dengan menganalisis faktor yang melatarbelakangi pemilihan tingkat tutur. Teori tingkat tutur yang diajukan oleh Poedjasoedarma (1979) dan Harjawiyaya (2001) digunakan sebagai pisau analisis.Metode yang digunakan dalam penelitian ini adalah metode kualitatif deskriptif, dengan teknik pengumpulan data menggunakan teknik simak kemudian ditranskripsi. Sumber data penelitian ini adalah tuturan tokoh-tokoh dalam film Kartini. Hasil penelitian ini menunjukan bahwa faktor yang menguatkan pemilihan tingkat tutur adalah status sosial, bukan relasi kekerabatan atau umur.
\end{abstract}

Kata kunci: tingkat tutur bahasa Jawa; film Kartini; kesantunan; Ngoko; Krama

\section{SPEECH LEVEL OF JAVANESE LANGUAGE IN KARTINI FILM}

\author{
Novia Ayu Rizky ${ }^{1}$, and Dwi Puspitorini ${ }^{2}$ \\ Fakultas Ilmu Budaya Universitas Indonesia \\ Email: novia.ayu51@ui.ac.id, ${ }^{1}$ dwi.puspitorini@ui.ac.id ${ }^{2}$
}

\begin{abstract}
This study discusses the level of speech in Javanese languange with structural and sociolinguistic approaches. The Javanese people in the 19th century that were portrayed in the Kartini film, are the Javanese people who respected someone of noble descent. This can be seen in the use of the level of speech in Javanese language of Ngoko and Krama when the speaker speaks with a speech partner who is a noble. The research was conducted to answer the question of how speakers speak to partners in Javanese society. A structural approach is used to determine the form of speech level. The sociolingistic approach is done by analyzing the factors behind the selection of speech levels. Speech level theory proposed by Poedjasoedarma (1979) and Harjawiyaya (2001) was used as the analysis knife. The method used in this study is descriptive qualitative method, with data collection techniques using referral techniques then transcribed. The data source of this research is the speech of the characters in Kartini film. The results of this study indicate that the factors that strengthen the selection of speech levels are social status, not kinship relations or age.
\end{abstract}

Key words: Javanese speech level; Kartini film; etiquette; Ngoko; Krama 


\section{PENDAHULUAN}

Masyarakat Jawa dalam film Kartini cenderung menunjukkan sosok yang sopan di hadapan orang lain. Kesopanan tersebut ditunjukkan dengancara berperilaku danbahasa yang digunakan ketika bertutur. Unggah-ungguh bahasa Jawa yang secara jelas dapat dibedakan, pada prinsipnya hanya ada dua macam, yaitu berbentuk Ngoko dan Krama (Sasangka, 2009). Dalam bertutur,masyarakatJawa menggunakan bahasa yang halus ketika bertutur dengan seseorang yang dihormati.Bahasa yang digunakan tokoh-tokoh dalam film Kartini lebih dominan menggunakan bahasa Jawa Ngoko dan Krama. Hal tersebut disebabkan oleh film Kartini yang berlatardi daerah Jepara khususnya wilayah Keraton.Bahasa Jawa yang digunakan dalam film Kartini bertujuan untuk berbagai hal.

Bahasa Jawa memiliki tingkat tutur (speech level). Hal itu menunjukkan bahwa masyarakat Jawa memiliki sistem kode yang mengatur relasi antara penutur $\left(\mathrm{O}_{1}\right)$, mitra tutur $\left(\mathrm{O}_{2}\right)$, dan orang yang dituturkan $\left(\mathrm{O}_{3}\right)$. Penggunaan tingkat tutur yang berbeda-beda diatur berdasarkan hubungan tersebut. Orang Jawa memiliki kepekaan untuk memilih tingkat tutur yang tepat karena menentukan rasa hormat kepada mitra tutur atau yang dituturkan. Tingkat tutur adalah variasi bahasa yang perbedaannya ditentukan oleh sikap pembicara kepada mitra bicara atau orang ketiga yang dibicarakan(Wedhawati \& Dkk, 2006).

Secara morfologis dan sintaktis dikenal ada dua tingkat tutur bahasa Jawa, yaitu Ngoko dan Krama. Secara leksikal, ada tiga tingkat tutur bahasa Jawa, yaitu Ngoko, Krama Andhap, dan Krama Inggil. Adapun pendekatan sosiolinguistik melihat tingkat tutur sebagai penggunaan bahasa Jawa dalam berinteraksi antara penutur dan mitra tutur. Adapun secara sosiolinguistik berbagai pendapat, Poedjasoedarma (1979) membedakan 3 jenis tingkat tutur, yaitu Ngoko, Krama, Madya. Poedjasoedarma menjelaskan arti ketiga tingkat tutur tersebut sebagai berikut.

Tingkat tutur Ngoko mencerminkan rasa tak berjarak antara $\mathrm{O}_{1}$ terhadap $\mathrm{O}_{2}$. Tingkat Tutur Krama adalah tingkat yang memancarkan arti penuh sopan santun. Tingkat tutur Madya adalah tingkat tutur menengah yang mencerminkan perasaan sopan secara sedang-sedang saja.

Lebih lanjut Poedjasoedarma (1979) menjelaskan ada dua hal yang sangat penting untuk menentukan penggunaan tingkat tutur, yaitu (1) tingkat formalitas hubungan antara $\mathrm{O}_{1}$ dan $\mathrm{O}_{2}$, (2) status sosial yang dimiliki oleh $\mathrm{O}_{2}$. Tingkat formalitas 
ditentukan berdasarkan (1) tingkat keakraban hubungan dengan $\mathrm{O}_{2}$, (2) tingkat keangkeran $\mathrm{O}_{2}$, dan (iii) umur $\mathrm{O}_{2}$ (Poedjasoedarma \& dan Pengembangan Bahasa, 1979).

Bambang Kaswanti Purwa (dalam Mulyanto, 2015) mempersoalkan hubungan antara pembicara dengan lawan bicara yang bersifat simetris dan asimetris sebagai faktor penentu pemilihan tingkat tutur Ngoko atau Krama. Haryana Harjawiyana dkk (2001) menyampaikan tujuh faktor yang menentukan sikap penutur dalam menempatkan diri secara benar melalui pemilihan tingkat tutur Ngoko atau Krama, yaitu (1) umur, (2) kekerabatan (peprenahan), (3) derajat pangkat, (4) derajat semat, (5) darah (keturunan), (6) kualitas pribadi (luhuring pribadi), (7) perkenalan (tetepangan).

Percakapan antara $\mathrm{O}_{1}$ dan $\mathrm{O}_{2}$ di bawah ini memperlihatkan pemilihan tingkat tutur Krama saat seseorang anak berbicara kepada ibunya. Sebaliknya, sang ibu memilih tingkat tutur Ngoko dalam merespons tuturan anaknya.

\section{Percakapan 1 (Buku Ajar PBJ 2 FIB UI)}

$\mathrm{O}_{1} \quad$ : “Bu dinten menika olah menapa?” 'Bu, Hari ini masak apa?'

$\mathrm{O}_{2} \quad$ : "Piye yen olah asem-asem?" 'Bagaimana kalau masak asem-asem?'

Penutur, yang adalah seorang anak, menempatkan diri secara benar di hadapan ibunya dengan memilih tingkat tutur Krama. Relasi antara anak dan orang tua bersifat asimetris, baik dilihat dari faktor umur, kedudukan, maupun kekerabatan.

Namun, tidak selamanya seorang anak memilih tingkat tutur Krama kepada orang tuanya. Percakapan 2 berikut ini terjadi antara ibu $\left(\mathrm{O}_{1}\right)$ dan anaknya $\left(\mathrm{O}_{2}\right)$.

\section{Percakapan 2 (Buku Ajar PBJ 2 FIB UI)}

O1 : "Ras, cepakna layah, munthu, talenan, lading, lan parut"

'Ras, siapkan layah, ulekan, talenan, pisau dan parutan'

O2 : "Iya Bu, arep olah apa ta?"

'Iya Bu, mau masak apa sih?'

Sebagaimana dalam Percakapan 1, dalam Percakapan 2 sang ibu $\left(\mathrm{O}_{1}\right)$ menggunakan tingkat tutur Ngoko kepada anaknya. Namun, sang anak $\left(\mathrm{O}_{2}\right)$ tidak menggunakan tingkat tutur Krama kepada ibunya. Dia memilih menggunakan tingkat tutur Ngoko.

Percakapan 1 dan 2 memiliki latar situasi yang sama. Relasi antara $\mathrm{O}_{1}$ dan $\mathrm{O}_{2}$ sama-sama bersifat asimetris. Meskipun faktor sosiolinguistiknya sama, pada 
kenyataannya, tingkat tutur yang dipilih oleh seorang anak kepada orang tuanya berbeda. Pada umumnya peneliti terdahulu sepakat bahwa orang tua menggunakan tingkat tutur Ngoko kepada anaknya dan sebaliknya seorang anak seharusnya menggunakan tingkat tutur Krama kepada orang tuanya. Percakapan 2 memperlihatkan adanya perubahan relasi anak dan orang tua yang menjadi bersifat simetris.

Meskipun ada berbagai pendapat tentang tingkat tutur bahasa Jawa dilihat dari sudut pandang sosiolinguistik, tetapi para peneliti terdahulu berpendapat sama bahwa faktor pemilihan tingkat tutur dilatarbelakangi oleh nilai sopan santun yang ada di dalam masyarakat Jawa. Rasa hati merupakan faktor utama yang paling menentukan (dalam Mulyanto, 2015). Akan tetapi, rasa hati tersebut tidak selalu sesuai dengan sistem kode yang dijelaskan oleh para ahli sebagaimana diperlihatkan melalui contoh percakapan berikut ini.

Percakapan 3 di bawah ini diambil dari film Kartini yang berlatar belakang situasi di lingkungan bangsawan Jawa di Keraton pada abad 19.

\section{Percakapan 3}

$\mathrm{O}_{1} \quad$ : "Ni emoh, Bu. Ni emoh dadi Raden Ayu.

'Ni tidak mau Bu, Ni tidak mau menjadi Raden Ayu'

O2 : "Inggih, Ndara."

'Iya, Tuan Putri'

Percakapan 3 terjadi antara Kartini sebagai penutur $\left(\mathrm{O}_{1}\right)$ dengan ibunya, Ngasirah, sebagai mitra tutur $\left(\mathrm{O}_{2}\right)$. Kartini adalah anak dari RM Adipati Ario Sosroningrat dan Ngasirah. Dalam film Kartini, terdapat tradisi seorang Bupati harus menikah dengan bangsawan. Untuk menjadi Bupati Jepara, ayah Kartini, RM Adipati Ario Sosroningrat memadu Ngasirah dengan menikahi seorang priyayi, Raden Ajeng Moerjam yang merupakan keturunan dari Raja Madura. Oleh sebab itu, Kartini memiliki dua sosok ibu. Ibu kandungnya adalah Ngasirah, berstatus sebagai rakyat biasa bukan keturunan bangsawan. Ibu tirinya bernama Raden Ayu Moerjam, keturunan bangsawan.

Pada percakapan 3, Kartini menggunakan tingkat tutur Ngoko, sedangkan ibunya menggunakan tingkat tutur Krama. Percakapan tersebut tidak sesuai dengan sistem kode sebagaimana dijelaskan oleh para ahli (Poedjasoedarma, 1979, Bambang, 1991, Haryana, 2002, Mulyanto, 2015). Berdasarkan faktor umur, ibu dari Kartini jelas lebih 
tua daripada anaknya. Berdasarkan faktor kekerabatan, orang tua seharusnya tidak menggunakan tingkat tutur Krama kepada anaknya.

Tidak sesuainya pilihan tingkat tutur tersebut dengan aspek sosiolinguistik yang dijelaskan oleh peneliti terdahulu tersebut memicu pemilihan topik penelitian ini. Penggunaan berbagai ragam tingkat tutur bahasa Jawa dalam dalam film Kartini menjadi data yang perlu dipertimbangkan untuk mengamati aspek sopan santun yang melatarbelakangi pemilihan tingkat tutur. Penelitian ini dilakukan untuk menjawab pertanyaan bagaimana cara pandang penutur terhadap mitra tutur di dalam masyarakat Jawa di dalam film Kartini. Film Kartini garapan Hanung Bramantyo yang dibuat pada tahun 2017 menjadi sumber data penelitian ini. Teori sosiolinguistik tentang tingkat tutur, khususnya yang berkaitan dengan faktor yang mempengaruhi pemilihan tingkat tutur, dari Soepomo Poedjasoedarma(1979) dan Harjawiyana (2001) digunakan untuk mencapai tujuan penelitian ini. Hasil penelitian ini diharapkan dapat menjelaskan faktor penentu pemilihan tingkat tutur yang menjadi kriteria kesantunan berbahasa dalam masyarakat Jawa. Temuan penelitian ini akan melengkapi pemahaman sistem kode masyarakat Jawa yang mengatur relasi antara penutur dan mitra tutur.

Terdapat beberapa penelitian terdahulu tentang tingkat tutur bahasa Jawa yang dilakukan dengan pendekatan sosiolinguistik (Muhid, 2011, Wajdi 2013). Muhid (2011) meneliti penggunaan tingkat tutur bahasa Jawa pada masyarakat Samin di Blora, sedangkan Wajdi (2013) meneliti penggunaan tingkat tutur bahasa Jawa di Jawa Timur. Berdasarkan leksikonnya, Muhid (2011) membagi tingkat tutur menjadi 3, yaitu Ngoko, Madya, dan Krama. Muhid menganalisis faktor yang melatarbelakangi pemilihan ketiga tingkat tutur tersebut. Muhid menyimpulkan bahwa pertimbangan yang digunakan untuk memilih tingkat tutur ada dua, yaitu faktor hubungan sosial antarpenutur (ketidakakraban, keangkeran) dan status sosial penutur (pendidikan). Konsep tingkat tutur bahasa Jawa yang dijelaskan Poedjasoedarma (1979) digunakan Muhid sebagai dasar analisis.

Dalam artikelnya Muhid menjelaskan bahwa penutur yang merasa lebih muda daripada mitra tuturnya akan menggunakan tingkat tutur Krama ketika bertutur. Hal tersebut dilakukan untuk menghormati mitra tuturnya. Ketika seorang penutur berbicara dengan orang yang usianya lebih tua, dia akan menggunakan tingkat tutur Krama, sebaliknya mitra tuturnya akan menggunakan tingkat tutur Ngoko (Muhid, 2011). 
Percakapan 4 di bawah ini adalah contoh penggunaan tingkat tutur yang diteliti oleh Muhid. Seorang anak $\left(\mathrm{O}_{1}\right)$ berbicara dengan neneknya $\left(\mathrm{O}_{2}\right)$.

\section{Percakapan 4}

O1: "Lha tiyang samin sangkak niku nggih larene pinten, Mbah?”

Lha (orang) Samin Sangkak itu anaknya berapa, Mbah? "

O2: "Ya, loro, lanang wedok."

Ya, dua, laki-laki dan perempuan.

Menurut Muhid, seorang anak akan menggunakan tingkat tutur Krama kepada neneknya, sebaliknya nenek akan menggunakan tingkat tutur Ngoko kepada cucunya. Penelitiannya melihat satu faktor penentu pemilihan tingkat tutur, yaitu usia. Perbedaan usia menjadi penentu pemilihan tingkat tutur. Dalam hal ini, penelitiannya tidak mengamati faktor lain, misalnya hubungan kekerabatan atau status sosial.

Penelitian yang dilakukan oleh Wajdi (2013) tentang Sistem Kesantunan Masyarakat Tutur Jawa menjelaskan hal yang berbeda. Wajdi menggunakan teori sosiolinguistik dari Brown \& Gilman. Menurutnya, faktor utama yang mempengarui penggunaan tingkat tutur adalah faktor kuasa atau ketidaksetaraan (Wajdi, 2013). Penggunaan tingkat tutur yang berbeda ketika bertutur menandakan bahwa mereka memiliki perbedaan sosial. Salah satu penutur memiliki kuasa atau kedudukan di dalam suatu tuturan. Percakapan 5 di bawah ini memperlihatkan penggunaan tingkat tutur yang diteliti oleh Wajdi. Percakapan terjadi antara seorang bapak $\left(\mathrm{O}_{1}\right)$ dengan anaknya $\left(\mathrm{O}_{2}\right)$.

\section{Percakapan 5}

$$
\begin{aligned}
& \mathrm{O}_{1}: \quad \text { "Seka }{ }^{1} \text { ngomah apa seka sekolahan kowe?” } \\
& \text { 'Kamu dari rumah apa dari sekolahan?' } \\
& \mathrm{O}_{2} \text { : } \quad \text { 'Saking griya, kula menawi dinten Setu mboten ndherek." } \\
& \quad \text { 'Dari rumah, kalau hari Sabtu saya tidak ikut.' }
\end{aligned}
$$

Menurut Wajdi (2013), keluarga penutur menerapkan prinsip struktur hierarkis, yaitu ayah adalah atasan bagi bagi putra-putrinya, sedangkan putra-putrinya merupakan bawahan dari ayahnya. Dalam penelitiannya dijelaskan bahwa anaknya menggunakan tingkat tutur Krama sebab anaknya mengetahui dengan jelas kalau ayahnya memiliki kuasa di dalam keluarga. (Wajdi, 2013).

\footnotetext{
${ }^{1}$ seka lengg. ptj: saka, sangka

Baoesastra Djawa(Poerwadarminta, 1939)
} 
Baik Muhid (2011) maupun Wajdi (2013) menjelaskan satu faktor yang hadir pada peristiwa tutur dalam menjelaskan alasan pemilihan tutur. Mereka tidak menjelaskan bagaimana jika ada lebih dari satu faktor yang bertolak belakang hadir pada satu peristiwa tutur. Faktor mana yang mendominasi pemilihan tingkat tutur? Rumpang tersebut akan diisi oleh penelitian ini. Film Kartini menyajikan beberapa peristiwa tutur yang tidak dapat dianalisis hanya dengan mempertimbangkan satu faktor sebagai alasan pemilihan tingkat tutur, seperti yang dilakukan oleh peneliti terdahulu.

\section{METODE PENELITIAN}

Pada penelitian ini, teori-teori yang digunakan untuk menjawab permasalahan adalah teori sosiolinguistik tentang tingkat tutur oleh Poedjasoedarma (1979) dan Harjawiyana (2001). Poedjasoedarma (1979) dalam buku Tingkat Tutur Bahasa Jawa mengemukakan "Tingkat tutur adalah suatu sistem kode penyampaian rasa kesopanan yang di dalamnya terdapat unsur kosakata tertentu, aturan sintaksis tertentu, aturan morfolgi, dan fonologi tertentu."

Selanjutnya, Harjawiyana (2001) dalam buku Marsudi Unggah-Ungguh Basa Jawa menjelaskan bahwa salah satu cara menghormati orang lain dilakukan dengan memperhatikan bahasa yang digunakan ketika bertutur. Adapun pemilihan bahasa seseorang dapat dilihat berdasarkan umur, status sosial, dan hubungan kekerabatan antara penutur dan mitra tutur. Teori Poedjasoedarma dan Harjawiyana digunakan untuk mengindentifikasi bentuk tingkat tutur berdasarkan ciri gramatikal dan kosa kata. Selanjutnya, dilakukan identifikasi faktor penentu pemilihan tingkat tutur yang menjadi kriteria kesantunan berbahasa dalam masyarakat Jawa berdasarkan relasi hubungan penutur $\left(\mathrm{O}_{1}\right)$ dan mitra tutur $\left(\mathrm{O}_{2}\right)$.

Penelitian ini menggunakan metode kualitatif deskriptif yaitu mengkaji fokus kepada deskripsi dan penempatan data pada konteksnya masing-masing. Tujuan penelitian deskriptif kualitatif menggambarkan realita yang sebenarnya pada objek sehingga memperoleh data yang objektif. Sumber data penelitian ini adalah dalam film Kartini karya sutradara Hanung Bramantyo yang dibuat pada 2017. Penelitian dilakukan melalui tiga tahap, yaitu (i) penyediaan data; (ii) analisis data; (iii) penyajian data. Merujuk pada penjelasan Soedaryanto (2015) tentang metode dan teknisi analisis bahasa, ada tiga kegiatan yang dilakukan pada tahap penyediaan data, yaitu (i) 
mengumpulkan data yang dilakukan dengan cara melakukan transkripsi otografis berdasarkan kaidah ejaan bahasa Jawa; (ii) memilih dan memilah data; (iii) menata data berdasarkan tingkat tutur Ngoko dan Krama beserta subjenisnya.

Penelitian ini bertujuan mempertajam hasil penelitian terdahulu. Untuk menjawab pertanyaan penelitian dilakukan langkah analisis data sebagai berikut. Pertama, mengindentifikasi bentuk tingkat tutur berdasarkan ciri gramatikal dan kosakata. Masalah gramatika memerlukan penjelasan yang berdimensi sosiolinguistik(Wijayana, 2013). Tuturan tokoh-tokoh dalam film Kartini tersebut dilihat bentuk tingkat tuturnya melalui pendapat ciri gramatikal dan kosakata tingkat tutur bahasa Jawa yang dijelaskan oleh Poedjasoedarma (1979) dan Ki Padmosusastro (dalam Mulyanto 2015). Kedua, mengidentifikasi faktor-faktor yang mempengaruhi penggunaan tingkat tutur bahasa Jawa berdasarkan pendapat Harjawiyana (2001). Analisis faktor penggunaan tingkat tutur Ngoko dan Krama dilakukan berdasarkan relasi hubungan penutur $\left(\mathrm{O}_{1}\right)$ dan mitra tutur $\left(\mathrm{O}_{2}\right)$. Pengamatan relasi hubungan penutur dan mitra tutur dilihat berdasarkan umur, status sosial, dan hubungan kekerabatan antara penutur dan mitra tutur.

Pada tahap penyajian hasil analisis data, penelitian ini menggunakan metode penyajian informal. Metode penyajian adalah perumusan dengan kata-kata biasa dengan terminologi yang teknis sifatnya tanpa lambang-lambang (Sudaryanto, 2015: 241). Penyajian hasil analisis data berwujud penjelasan yang berkaitan dengan klasifikasi tingkat tutur secara gramatikal, serta klasifikasi penentu tingkat tutur secara sosiolinguistik.Penjelasannya berupa uraian yang berwujud kalimat-kalimat yang diikuti pemerian secara terperinci.

\section{HASIL DAN PEMBAHASAN}

Pada bagian pembahasan ini diuraikan hasil analisis tingkat tutur bahasa Jawa yang ditinjau dengan pendekatan sosiolinguistik. Analisis sosiolinguistik dilakukan terhadap bahasa Jawa Ngoko dan Krama untuk memperlihatkan faktor-faktor yang melatarbelakangi penggunaan tingkat tutur Ngoko dan Krama. Sebelum menguraikan hasil analisis sosiolinguistik, pembahasan ini menguraikan hasil analisis tingkat tutur bahasa Jawa yang ditinjau dengan pendekatan gramatikal. Secara gramatikal ada dua bentuk tingkat tutur bahasa Jawa, yaitu Ngoko dan Krama. Analisis gramatikal 
dilakukan untuk memperlihatkan ciri gramatikal bahasa Jawa Ngoko dan Krama yang ditemukan di dalam sumber data.

\section{Analisis Gramatikal}

Secara gramatikal, tingkat tutur Ngoko dan Krama berbeda. Menurut Maryono Dwiraharjo (dalam Mulyanto, 2015), perbedaan tingkat tutur yang dilihat dari aspek gramatikal ditentukan oleh perbedaan (i) pilihan kata yang meliputi kata tugas, pronimona persona, adverbia, demostrativa, pronomina yang menyatakan kepemilikan, numeralia, dan interogativa; (ii) afiks.

\subsection{Ngoko}

Tingkat tutur Ngoko memiliki pronomina, afiks, dan kata tugas bentuk Ngoko(Mulyanto, 2015). Afiks yang termasuk ke dalam tingkat tutur Ngoko adalah tak-, kok-, di-, -(n)e, -(k)ake. Adapun kata tugas Ngoko antara lain lan, karo, marang, menyang, utawa. Pronomina persona aku, kowe, dheweke. Selain itu, adverbia, pronomina yang menyatakan kepemilikan, dan pronomina demonstrativanya juga Ngoko. Adverbia antara lain wis, arep, lagi, durung, isih, banget, ora, dudu, mung. Pronomina demonstratif $i k i$, iku, kuwi, kae. Pronomina yang menyatakan kepemilikan $k u,-m u,-e l-n e$.

Ciri utama tingkat tutur Ngoko adalah keseluruhan leksikon dalam rangakaian kalimat Ngoko menggunakan leksikon Ngoko, bukan leksikon yang lain. Dari hasil analisis data, ditemukan bentuk tingkat tutur yang keseluruhan leksikonnya adalah Ngoko. Berikut di bawah ini adalah contohnya.

\section{Percakapan 6}

$\mathrm{O}_{1}$ : "NdhukTrinil ngadeg. Lungguh karo Rama. Dina iki wis dadi wancine kowe dadi Raden Ayu. Ibu lan Rama wis ngenteni 16 taun. Piye? Kowe sanggup, ta?"

'Nak, Trinil berdiri. Duduk sama Rama. Hari ini sudah waktunya kamu menjadi Raden Ayu. Ibu dan Bapak sudah menunggu selama 16 tahun. Bagaimana? Kamu sanggup kan?'

Percakapan 6 merupakan percakapan antara RM Adipati Ario Sosroningrat sebagai penutur $\left(\mathrm{O}_{1}\right)$ dengan putrinya, Kartini, sebagai mitra tutur $\left(\mathrm{O}_{2}\right)$. Kalimat yang diujarkan $\mathrm{O}_{1}$ merupakan bahasa Jawa Ngoko. Hal tersebut dapat dilihat dari pronomina persona kedua yang digunakan oleh $\mathrm{O}_{1}$ adalah pronomina pesoa kedua Ngoko, yaitu 
kowe. Selain pronomina, ciri lain yang menunjukan bahwa tuturan tersebut Ngoko adalah afisk -ne pada kata wancine. Kata wis dan piye juga merupakan adverbia Ngoko. Keseluruhan kalimat pada Percakapan 6 mengandung kosakata dan unsur gramatikal Ngoko.

Pada data penelitian ini juga ditemukan tingkat tutur Ngoko Antiya Basa, yaitu secara gramatikal adalah Ngoko tetapi mengandung kosakata Krama Inggil. Contoh:

\section{Percakapan 7}

$\mathrm{O}_{1}$ : "Singa, dhawuhe Kartini padha karo dhawuhe aku. Sing nentang Kartini padha karo nentang aku. Ngerti ta?"

'Singa, perintah Kartini sama seperti perintahku, yang menentang Kartini sama dengan menentangku. Mengerti kan?'

Percakapan 7 merupakan percakapan antara RM Adipati Ario Sosroningrat sebagai penutur $\left(\mathrm{O}_{1}\right)$ dengan pengukir kayu, Singawirya, sebagai mitra tutur $\left(\mathrm{O}_{2}\right)$. Kalimat pada Percakapan 7 adalah Ngoko karena secara gramatikal mengandung ciri Ngoko, yaitu pronomina persona $a k u$, kata tugas Ngoko yaitu sing, padha, ta, adverbia padha, serta afiks -e.Namun, kalimat Ngoko tersebut mengandung nomina Krama yaitu dhawuh yang dilekati afiks Ngoko -e. Nomina Krama Inggildhawuh digunakan pada kalimat Ngoko karena membicarakan orang ketiga $\left(\mathrm{O}_{3}\right)$ yang dihormati $\mathrm{O}_{2}$, yaitu Kartini. Dalam percakapan 7, terdapat nomina "dhawuhe aku," yang secara morfologis seharusnya menjadi dhawuhku. Afiks - e yang melekat pada nomina dhawuh, seharusnya diikuti dengan nomina persona, dan bukan pronomina aku.

\section{Percakapan 8}

O1: "Raden Ajeng Moerjam pundhutengarwa, iki kanggo becike wong akeh para kawula."

"Raden Ajeng Moerjam ambillah sebagai istri, ini untuk kebaikan seluruh rakyat.'

Percakapan 8 merupakan percakapan antara ayah dari RM Adipati Ario Sosroningrat sebagai penutur $\left(\mathrm{O}_{1}\right)$ dengan anaknya, RM Adipati Ario Sosroningrat, sebagai mitra tutur $\left(\mathrm{O}_{2}\right)$. Tuturan tersebut berbentuk Ngoko Antiya Basa. Ciri gramatikal Ngoko berupa afiks -e (pada kata becike) dan -en (pemarkah imperatif). Afiks -en yang merupakan pemarkah imperatif ragam Ngoko tidak disebutkan oleh peneliti terdahulu (Poedjasoedarma, Ki Padmosusastro). Ciri gramatikal Ngoko juga tampak dari pemakaian kata tugas Ngoko, yaitu kanggo. Selain kata tugas, terdapat nomina Ngoko 
yaitu wong, pronominal demosntratif $i k i$, dan numeralia tak tentu akeh. Namun, dalam tuturan yang berbentuk Ngoko tersebut terdapat verba dan nomina Krama Inggil yaitu pundhut dan garwa karena membicarakan orang ketiga $\left(\mathrm{O}_{3}\right)$ yang dihormati $\mathrm{O}_{2}$ dan $\mathrm{O}_{1}$. Tuturan pada Percakapan 8 juga merupakan tingkat tutur Ngoko Antiya Basa.

\subsection{Krama}

Ciri utama tingkat tutur Krama adalah leksikon Krama dan bukan leksikon yang lain. Sama seperti tingkat tutur Ngoko, penanda kosakata tingkat tutur Krama adalah pronomina, afiks, kata tugas, verba (Mulyanto, 2015). Poedjasoedarma (1979) juga berpendapat sama. Bentuk tingkat tutur Krama mengandung kata-kata tugas dari ragam Krama. Kalau kata-kata tugas sudah mengandung Krama berarti bahwa kata-kata lainnya paling sedikit juga Krama. Pronomina yang termasuk pronomina Krama adalah kula, panjenengan, piyambakipun. Afiks yang termasuk imbuhan Krama adalah -dipun, -(n)ipun, -(k)aken. Adapun adverbia yang termasuk Krama adalah boten, sampun. Kata tugas Krama misalnya kaliyan, dhateng, dhumateng, wonten ing. Selain itu, adverbia, pronomina demonstratif, dan interogatif juga Krama. Adverbia antara lain sampun, badhe, saweg, dereng, taksih, sanget, mboten, sanes, namung. Pronomina demonstratif antara lain menika, mekaten. Tingkat tutur Krama tidak memiliki pronomina yang menyatakan kepemilikan. Untuk menyatakan kepemilikan digunakan konstruksi frasa nominal, misalnya putu kula atau anakipun kula. Afiks -ipun pada konstruksi anakipun kula adalah ligatur, bukan pronomina.

Dari hasil analisis data, ditemukan bentuk tingkat tutur yang keseluruhan leksikonnya adalah Krama, berikut adalah contoh bentuk tingkat tutur Krama yang seluruh leksikonnya adalah Krama.

\section{Percakapan 9}

O1: "Kula sagah. Kula nampi pinagangan Kanjeng Adipati Jayaningrat saking Lembang. Ananging wonten saratipun."

'Saya bersedia. Saya menerima lamaran Kanjeng Adipati Jayaningkrat dari Lembang. Tetapi ada syaratnya.'

Percakapan 9 merupakan percakapan antara Kartini sebagai penutur $\left(\mathrm{O}_{1}\right)$ dengan orang tuanya, RM Adipati Ario Sosroningrat dan RA Moerjam (ibu tiri), sebagai mitra tutur $\left(\mathrm{O}_{2}\right)$. Tuturan pada Percakapan 9 berbentuk Krama. Hal tersebut terlihat dari pronomina yang digunakan dalam tuturan adalah pronomina Krama yaitu kula. Selain 
pronomina, ciri lain yang menunjukan tuturan tersebut Krama adalah penggunaan kata tugas Krama yaitu saking. Afiks yang digunakan dalam tuturan tersebut juga adalah afiks Krama yaitu -ipun yang ada pada kata saratipun.

Pada data penelitian ini ditemukan kosakata Ngoko yang terdapat di dalam kalimat Krama. Berikut di bawah ini adalah contohnya.

\section{Percakapan 10}

\section{O1: "Wau iku tembaru kula sing direbut kalih Ndara Ajeng Kartini."}

'Tadi itu suguhan saya yang direbut oleh Tuan Putri Kartini.

Percakapan 10 merupakan percakapan antara Mbok sebagai penutur $\left(\mathrm{O}_{1}\right)$ dengan Atma sebagai mitra tutur $\left(\mathrm{O}_{2}\right)$. Keduanya adalah abdi dalem. Atma adalah salah satu abdi dalem kepercayaan keluarga Keraton. Usianya lebih tua daripada Mbok. Tuturan 10 secara gramatikal berbentuk Krama. Hal tersebut dapat dilihat dari pemakaian pronomina persona Krama, yaitu kula. Selain itu, ciri lain yang menunjukan tuturan tersebut Krama adalah penggunaan kata tugas Krama, yaitu kalih. Namun, dalam kalimat Krama tersebut terdapat kata Ngoko yaitu iku dan sing. Peneliti terdahulu antara lain Poedjasoedarma dan Ki Padmususatro mencatat adanya subjenis Krama yaitu Wredhakrama yang mengandung mengizinkan kehadiran afiks Ngoko dan kata-kata seperti sing, kang, mung, ning di dalam kalimat Krama. Tidak disebutkan adanya kemungkinan kehadiran pronomina Ngoko (iku misalnya) sebagaimana diperlihatkan dalam Percakapan 10.

Kalimat yang juga termasuk ke dalam subjenis Wredhakrama diperlihatkan melalui contoh berikut ini.

\section{Percakapan 11}

O1: "Dalem sewu, Ndara Ajeng, Kula dipundhawuh Ndara Slamet, Ndara Kartini boten kepareng medal saking Kadipaten. Kula kemawon singngaterke."

"Mohon maaf, Tuan Putri. Saya diperintah Tuan Slamet, Ndara tidak diizinkan keluar dari Kadipaten. Saya saja yang mengantarkan'

Percakapan 10 merupakan percakapan antara Atma sebagai penutur $\left(\mathrm{O}_{1}\right)$ dengan Kartini sebagai mitra tutur $\left(\mathrm{O}_{2}\right)$. Tuturan yang diucapkan Atma adalah bahasa Krama. Hal itu ditandai dengan penggunaan pronomina Krama yaitu kula, adverbia boten, kemawon, kata tugas saking. Baik afiks Kramadipun- (dipundhawuh) maupun afiks 
Ngoko -ke (ngaterke) digunakan di dalam tuturan tersebut. Juga ditemukan penggunaan kata Ngokosing. Ciri tersebut termasuk ke dalam jenis Wredhakrama.

\section{Analisis Sosiolinguistik}

Dalam masyarakat Jawa, rasa hormat dicerminkan melalui tingkat tutur yaitu Ngoko dan Krama yang digunakan untuk berkomunikasi. Ada beberapa faktor yang melatarbelakangi pemilihan tingkat tutur. Bagi orang Jawa, pilihan tingkat tutur mencerminkan rasa hormat yang sesuai dengan posisi penutur terhadap mitra tuturnya. Cara masyarakat Jawa menunjukan penghormatan dan kekakraban melalui bahasa Jawa jauh lebih terperinci dibandingkan dengan contoh manapun pada bahasa-bahasa Eropa (Geertz, 1981). Menurut Harjawiyana (2001) faktor yang mempengaruhi tingkat tutur Ngoko dan Krama antara lain adalah umur, kekerabatan, status sosial. Berikut di bawah ini dijelaskan faktor yang melatarbelakangi pemilihan tingkat tutur Ngoko dan Krama di dalam film Kartini.

\subsection{Ngoko}

Menurut Poedjasoedarma (1979) tingkat tutur Ngoko adalah tingkat tutur yang menunjukan hubungan yang tak berjarak antara penutur $\left(\mathrm{O}_{1}\right)$ dan mitra tutur $\left(\mathrm{O}_{2}\right)$. Ketika penutur merasa dirinya tidak ada jarak dengan kawan tutur, penutur akan menggunakan tingkat tutur Ngoko. Dalam film Kartini, tuturan Ngoko terjadi saat seorang ayah berbicara kepada anaknya. Hal itu juga dilakukan ketika adik-adik Kartini menggunakan tingkat tutur Ngoko terhadap Kartini sebab adik-adik Kartini merasa tidak ada jarak dengan Kartini. Keakraban merupakan salah satu faktor yang melatarbelakangi penggunaan tingkat tutur Ngoko.

Selain keakraban atau merasa tidak ada jarak dengan mitra tutur, faktor lain yang mempengaruhi penggunaan tingkat tutur Ngoko adalah status sosial. Tingkat tutur Ngoko digunakan oleh penutur yang status sosialnya lebih tinggi daripada mitra tutur. Ketika penutur mengetahui dengan jelas status sosial mitra tuturnya, penutur tidak ragu dalam memilih tingkat tutur.

Terdapat beberapa faktor yang penting ketika menentukan penggunaan tingkat tutur Ngoko pada saat bertutur dengan mitra tutur, yaitu relasi hubungan penutur dan mitra tutur, umur, status sosial penutur dan mitra tutur. Hal tersebut tercermin pada 
dialog di bawah ketika penutur memilih menggunakan tingkat tutur Ngoko saat bertutur dalam film Kartini:

\section{a. Status Sosial}

Menurut Harjawiyana (2001) salah satu faktor pemilihan tingkat tutur adalah keturunan atau status sosial. Pada dasarnya status sosial ditentukan oleh latar belakang mitra tutur, misalnya dia bergelar Raden Ajeng, Raden Mas. Adanya tingkat tutur Krama dan Ngoko menimbulkan keinginan untuk memperlihatkan status sosial penutur. Dalam film Kartini, seseorang yang berstatus sosial tinggi akan diberi penghargaan dan penghormatan yang tinggi. Orang tersebut merupakan sosok yang terhormat dalam masyarakat. Selain itu, keturunan atau status sosial seseorang menjadi faktor penting untuk memilih tingkat tutur. Ketika berbicara dengan seseorang yang merupakan keturunan terhormat atau bangsawan, penutur harus meninggikan bahasa yang digunakan.

Dari hasil analisis data, ditemukan peristiwa tutur Ngoko yang disebabkan oleh faktor status sosial. Berikut di bawah ini adalah contohnya.

\section{Percakapan 12}

\section{$\mathrm{O}_{1}$ : "Aku arep ngaterke tulisanku sing arep terbit sesuk menyang omahe Nyonya Ter H orst."}

'Aku akan mengantarkan tulisanku yang akan terbit besok ke rumah Nyonya Ter Horst.'

$\mathrm{O}_{2}$ : "Kula dipundhawuh Ndara Slamet, Ndara boten kepareng medal saking Kadipaten."

'Aku diperintah Tuan Slamet, Tuan Putri tidak boleh pergi dari Keraton.'

Dialog pada Percakapan 12 terjadi antara Kartini sebagai penutur $\left(\mathrm{O}_{1}\right)$ dengan Atma sebagai mitra tutur $\left(\mathrm{O}_{2}\right)$. Hubungan antara $\mathrm{O}_{1}$ dan $\mathrm{O}_{2}$ adalah pelayan dan Tuan Putrinya. $\mathrm{O}_{1}$ adalah keturunan bangsawan, sedangkan $\mathrm{O}_{2}$ adalah abdi dalem yang bekerja di Keraton. Pada peristiwa tutur di atas, $\mathrm{O}_{1}$ menggunakan tingkat tutur Ngoko, sedangkan $\mathrm{O}_{2}$ menggunakan tingkat tutur Krama. Ditinjau dari segi umur, $\mathrm{O}_{2}$ jauh lebih tua daripada $\mathrm{O}_{1}$. Jika mempertimbangkan faktor umur, seharusnya $\mathrm{O}_{1}$ menggunakan tingkat tutur Krama saat berbicara dengan $\mathrm{O}_{2}$. Sebaliknya $\mathrm{O}_{2}$ merespons tuturan $\mathrm{O}_{1}$ dengan memilih tingkat tutur Ngoko. Peristiwa tutur di atas memperlihatkan bahwa 
faktor status sosial lebih kuat mempengaruhi pemilihan tingkat tutur. Dalam peristiwan tutur tersebut, $\mathrm{O}_{2}$ menunjukan kesopanan dirinya terhadap $\mathrm{O}_{1}$ melalui penggunaan tingkat tutur Krama.

\section{Percakapan 13}

\section{$\mathrm{O}_{1}$ : "Singa, Dhawuhe Kartini padha karo dhawuhe aku. Sing nentang Kartini padha karo nentang aku. Ngerti?"}

'Singa, perintah Kartini sama dengan perintahku, yang menentang Kartini sama dengan menentangku. Mengerti?'

$\mathrm{O}_{2}$ : "Sendhika dhawuh."

'Baik.'

Dialog pada Percakapan 13 terjadi antara RM Adipati Ario Sosroningrat sebagai penutur $\left(\mathrm{O}_{1}\right)$ dengan pengukir kayu, Singawirya, sebagai mitra tutur $\left(\mathrm{O}_{2}\right)$. Relasi hubungan antara $\mathrm{O}_{1}$ dan $\mathrm{O}_{2}$ tidak akrab atau berjarak. Tingkat tutur yang digunakan oleh $\mathrm{O}_{1}$ adalah Ngoko. Hal tersebut membuktikan bahwa $\mathrm{O}_{1}$ mengetahui dengan jelas kedudukan dirinya jauh lebih tinggi daripada mitra tuturnya. Ditinjau dari faktor usia, umur $\mathrm{O}_{2}$ jauh lebih tua dibandingkan dengan $\mathrm{O}_{1}$. Dalam percakapan di atas, $\mathrm{O}_{2}$ menggunakan tingkat tutur Krama karena ingin menunjukan sikap sopan di hadapan Bupati Jepara melalui bahasa yang digunakannya.

\section{b. Umur}

Menurut Harjawiyana (2001) salah faktor yang mempengaruhi tingkat tutur adalah umur. Saat penutur berbicara dengan mitra tutur yang umurnya lebih muda, tingkat tutur yang digunakan adalah Ngoko. Masyarakat Jawa sangat menghormati perbedaan umur. Semakin tua seseorang orang tersebut semakin mempunyai wibawa. Untuk itu penggunaan tingkat tutur yang tepat sangat penting untuk menjaga sopan santun. Tingkat tutur yang digunakan mencerminkan sikap sopan atau tidaknya pada saat bertutur. Penjelasan di atas tercermin melalui percakapan dalam film Kartini berikut ini.

\section{Percakapan 14}

$\mathrm{O}_{1}$ : "H aryana? Wah pangling aku."

'Haryana? Wah pangling aku.'

$\mathrm{O}_{2}$ : "Inggih, Pakdhe. Sakmenika kula dadi Patih ing Pemalang." 'Iya, Pakdhe. Saya sekarang menjadi Patih di Pemalang.' 
Penutur $\left(\mathrm{O}_{1}\right)$ pada Percakapan 14 adalah RM Adipati Ario Sosroningrat yang sedang berbicara dengan Raden Mas Slamet sebagai mitra tutur $\left(\mathrm{O}_{2}\right)$. Keduanyaadalah bangsawan Jawa. Mereka berdua adalah rekan kerja di dalam pemerintahan Jawa. Umur $\mathrm{O}_{2}$ jauh lebih muda daripada $\mathrm{O}_{1}$. Oleh sebab itu, pada peristiwa tutur di atas, $\mathrm{O}_{1}$ menggunakan tingkat tutur Ngoko, sedangkan $\mathrm{O}_{2}$ menggunakan tingkat tutur Krama. Jika mempertimbangkan faktor status sosial yang sama-sama memiliki gelar bangsawan, seharusnya $\mathrm{O}_{1}$ menggunakan tingkat tutur Krama saat berbicara dengan $\mathrm{O}_{2}$. Sebaliknya, peristiwa tutur di atas memperlihatkan bahwa faktor umur lebih kuat mempengaruhi pemilihan tingkat tutur. Dalam tuturan di atas, penutur sudah mengetahui dengan jelas umur mitra tutur yang diajak bicara, sehingga penutur menggunakan tingkat tutur Ngoko. Dalam peristiwa tersebut, $\mathrm{O}_{1}$ menunjukan kesantunan dirinya terhadap $\mathrm{O}_{2}$ melalui penggunaan tingkat tutur Ngoko. Demikian pula, $\mathrm{O}_{2}$ menunjukan kesantunan dirinya terhadap $\mathrm{O}_{1}$ melalui penggunaan tingkat tutur Krama.

\title{
c. Hubungan kekerabatan
}

Salah satu faktor penentu pemilihan tingkat tutur adalah hubungan kekerabatan (Harjawiyana \& Supriya, 2001). Faktor ini berkaitan dengan tingkat keakraban hubungan antara $\mathrm{O}_{1}$ dan $\mathrm{O}_{2}$ dan tingkat keangkeran $\mathrm{O}_{2}$ (Poedjasoedarma, 1979). Poedjasoedarma menjelaskan bahwa tingkat keakraban hubungan ini penting sekali. Namun, dalam kaitannya dengan hubungan kekerabatan, tingkat keangkeran atau tingkat kehormatan menentukan pemilihan tingkat tutur. Pada masa lalu (utamanya sebelum kemerdekaan) hubungan antara anak dan orang tua, terutama pada keluarga bangsawan, didominasi dengan tingkat kehormatan terhadap orang tua. Tingkat kehormatan orang tua dilihat dari tinggi rendahnya kedudukan yang dimilikinya.

Dari hasil analisis data ditemukan peristiwa tutur yang sesuai dengan penjelasan Poedjasoedarma di atas.

\section{Percakapan 15}

\author{
$\mathrm{O}_{1}$ : "Wis wancine adhi-adhimu mlebu pingitan." \\ 'Sudah waktunya adik-adikmu masuk pingitan.' \\ $\mathrm{O}_{2}$ : “Dhawuh, Ibu." \\ 'Baik, Ibu.'
}


Dialog pada Percakapan 15 terjadi antara RA Moerjam sebagai penutur $\left(\mathrm{O}_{1}\right)$ dan Kartini sebagai mitra tutur $\left(\mathrm{O}_{2}\right)$. Status sosial $\mathrm{O}_{1}$ dan $\mathrm{O}_{2}$ adalah bangsawan. Pada peristiwa tutur di atas, $\mathrm{O}_{1}$ menggunakan tingkat tutur Ngoko, sedangkan $\mathrm{O}_{2}$ menggunakan tingkat tutur Krama. Pemilihan tingkat tutur pada peristiwa tuturan di atas dilatarbelakangi faktor hubungan kekerabatan $\mathrm{O}_{1}$ dan $\mathrm{O}_{2}$ yaitu ibu sambung dan anak. RA Moerjam menggunakan tingkat tutur Ngoko saat berbicara kepada anak tirinya, Kartini. Sebaliknya Kartini menggunakan tingkat tutur Krama karena dipicu oleh tingkat kehormatan RA Moerjam yang merupakan ibu sambungnya. Pilihan tersebut menunjukan kesopanan penutur terhadap mitra tuturnya.

\section{Percakapan 16}

\section{$\mathrm{O}_{1}$ : “Kanggo sapa panganan iku?" \\ 'Makanan itu untuk siapa?' \\ O2: “Kagem Nyonya Ovink-Soer, Mas Slamet." 'Untuk Nyonya Ovink-Soer, Mas Slamet.'}

Penutur $\left(\mathrm{O}_{1}\right)$ pada Percakapan 16 adalah RM Slamet yang sedang berbicara dengan Kartini, adiknya $\left(\mathrm{O}_{2}\right)$. Faktor hubungan kekerabatan yang dipicu oleh tingkat kehormatan juga melatarbelakangi pemilihan ragam tingkat tutur. Meskipun hubungan kakak-adik tidak berjarak (akrab), tetapi Kartini menggunakan tingkat tutur Krama saat berbicara dengan kakaknya. Faktor tingkat kehormatan RM Slamet di mata Kartini lebih memberatkan pemilihan tingkat tutur.

\subsection{Krama}

Menurut Poedjasoedarma (1979) tingkat tutur Krama merupakan tingkat tutur yang menunjukan arti kesopanan yang tinggi. Semakin tinggi tingkat tutur yang digunakan, maka semakin tinggi kesopanan seseorang tersebut. Tingkat tutur Krama menandakan adanya perasaan segan $\mathrm{O}_{1}$ terhadap $\mathrm{O}_{2}$, karena $\mathrm{O}_{2}$ adalah orang yang belum dikenal, berpangkat, umur lebih tua, dan yang lainnya (Poedjasoedarma \& dan Pengembangan Bahasa, 1979). Ketika penutur mengetahui dengan jelas dengan siapa dia bertutur, di mana dia bertutur, atau situasi bagaimana ketika dia bertutur, penutur mengetahui tingkat tutur apa yang akan dipakai ketika bertutur.

Tingkat tutur Krama digunakan oleh penutur $\left(\mathrm{O}_{1}\right)$ yang memiliki usia yang lebih muda dibandingkan dengan mitra tuturnya $\left(\mathrm{O}_{2}\right)$. Selain itu, ketidakakraban juga bisa menjadi faktor pemilihan tingkat tutur Krama, misalnya ketika berbicara dengan 
seseorang yang baru dikenal. Selain faktor umur dan hubungan kekerabatan, faktor lain yang mempengaruhi penggunaan tingkat tutur Krama adalah status sosial $\mathrm{O}_{2}$ yang lebih tinggi daripada $\mathrm{O}_{1}$.

Hasil analisis data film Kartini memperlihatkan bahwa tingkat tutur Krama lebih sering digunakan dalam kehidupan sehari-hari. Hal itu disebabkan latar film Kartini adalah lingkungan Keraton. Berikut di bawah ini dijelaskan faktor yang penting yang memicu penggunaan tingkat tutur Krama.

\section{a. Status sosial}

Seseorang yang memiliki status sosial tinggi akan dihargai melalui penggunaan tingkat tutur Krama yang digunakan oleh mitra tuturnya. Status sosial seseorang dalam masyarakat merupakan salah satu aspek penentu pemilihan tingkat tutur untuk menunjukan tingkat kesopanan penutur. Menurut Scollon (2001) faktor kekuasaan dapat menaikan tingkat kesopanan tuturan terhadap mitra tutur yang memiliki kekuasaan yang lebih tinggi. Status sosial ditentukan oleh latar belakang seseorang. Dari hasil analisis data, ditemukan peristiwa tutur Krama yang disebabkan oleh faktor status sosial. Berikut di bawah ini adalah contohnya.

\section{Percakapan 17}

$\mathrm{O}_{1}$ : "Nuwun sewu. Kula dipunutus Kanjeng Bupati damel unjukan lan panganan kanggo Meneer Ovink-Soer. Tiga, Landa sedaya."

"Mohon maaf. Saya diutus Kanjeng Bupati membuat makanan untuk tamu. Tiga, Belanda semuanya.'

$\mathrm{O}_{2}$ : "Landa? Landa sapa, pak Atma?"

'Belanda? Belanda siapa, Pak Atma?'

Dialog pada Percakapan 17 terjadi antara Atma $\left(\mathrm{O}_{1}\right)$ dan Roekmini $\left(\mathrm{O}_{2}\right)$. Hubungan antara $\mathrm{O}_{1}$ dan $\mathrm{O}_{2}$ adalah pelayan dan Tuan Putrinya. $\mathrm{O}_{1}$ adalah abdi dalem yang bekerja di Keraton, sedangkan $\mathrm{O}_{2}$ adalah keturunan bangsawan. Pada percakapan 17, $\mathrm{O}_{1}$ menggunakan tingkat tutur Krama, sedangkan $\mathrm{O}_{2}$ menggunakan tingkat tutur Ngoko. Ditinjau dari segi umur, $\mathrm{O}_{2}$ jauh lebih muda daripada $\mathrm{O}_{1}$. Jika mempertimbangkan faktor umur, seharusnya $\mathrm{O}_{1}$ menggunakan tingkat tutur Ngoko saat berbicara dengan $\mathrm{O}_{2}$. Sebaliknya, $\mathrm{O}_{2}$ merespons tuturan $\mathrm{O}_{1}$ dengan memilih tingkat tutur Krama. Peristiwa tutur di atas memperlihatkan bahwa faktor status sosial lebih kuat mempengaruhi pemilihan tingkat tutur. Dalam peristiwan tutur tersebut, $\mathrm{O}_{1}$ menunjukan kesopanan dirinya terhadap $\mathrm{O}_{2}$ melalui penggunaan tingkat tutur Krama. 


\title{
Percakapan 18
}

$\mathrm{O}_{1}$ : "Ni emoh, Bu. Ni emoh dadi Raden Ayu."

'Ni tidak mau, Bu. Ni tidak mau menjadi Raden Ayu.'

$\mathrm{O}_{2}$ : “Inggih, N dara."

'Iya, Tuan Putri.'

Dialog pada Percakapan 18 terjadi antara Kartini $\left(\mathrm{O}_{1}\right)$ dan Ngasirah $\left(\mathrm{O}_{2}\right)$. Ngasirah adalah ibu kandung Kartini. Status sosial Kartini lebih tinggi daripada Ngasirah. Kartini adalah bangsawan bergelar Raden Ajeng, sedangkan Ngasirah adalah abdi dalem yang bekerja di Keraton. Tingkat tutur yang digunakan oleh Kartini saat berbicara dengan Ngasirah, ibu kandungnya adalah Ngoko. Sebaliknya, Ngasirah menggunakan tingkat tutur Krama saat berbicara dengan Kartini, putri kandungnya. Jika mempertimbangkan faktor hubungan kekerabatan, seharusnya Ngasirah menggunakan Ngoko, sebaliknya Kartini seharusnya menggunakan Krama. Pada peristiwa tutur di atas, faktor status sosial lebih memberatkan daripada faktor hubungan kekerabatan. Pilihan tingkat tutur merupakan cermin kesopanan. Jadi meskipun Ngasirah adalah ibu kandung Kartini, oleh karena status sosialnya lebih rendah, Ngasirah harus menggunakan tingkat tutur Krama kepada Kartini. untuk menunjukkan kesopanan. Demikian pula, Kartini yang bangsawan menggunakan tingkat tutur Ngoko kepada ibu kandungnya yang status sosialnya rendah untuk menunjukkan kesopanannya.

\section{b. Umur}

Orang Jawa menghormati orang yang lebih tua. Oleh karena itu, salah satu faktor penentu pemilihan tingkat tutur Krama adalah umur. Faktor umur sebegai penentu tingkat tutur juga disebut oleh Harjawiyana (2001). Untuk menunjukkan rasa hormat dan kesopanan orang Jawa akan memilih tingkat tutur Krama saat berbicara orang yang lebih tua. Berikut di bawah ini peristiwa tutur dalam film Kartini yang menghadirkan tingkat tutur Krama dengan faktor umur sebagai pemicunya.

\section{Percakapan 19}

\author{
$\mathrm{O}_{1}$ : "Wau iku tembaru kula sing direbut kalih N dara J eng Kartini." \\ 'Tadi itu suguhan saya yang direbut oleh Tuan Putri Kartini.' \\ $\mathrm{O}_{2}$ : "Direbut piye? Direbut piye?" \\ 'Direbut bagaimana? Direbut bagaimana?'
}


Dialog pada Percakapan 19 terjadi antara Mbok $\left(\mathrm{O}_{1}\right)$ dan Atma $\left(\mathrm{O}_{2}\right)$. Keduanya memiliki status sosial yang sama, yaitu sebagai abdi dalem yang bekerja di dalam Keraton. Pada peristiwa tutur di atas, Mbokmenggunakan Krama saat berbicara dengan Atma, sedangkan Atma menggunakan Ngoko saat merespons tuturan Mbok. Mbok mengetahui umur Atmalebih tua, karena itu untuk menunjukkan rasa hormat dan menjaga kesopanan, Mbok menggunakan tingkat tutur Krama. Sebaliknya, Atma menggunakan tingkat tutur Ngoko untuk menjaga kesopanan.

\section{c. Hubungan kekerabatan}

Baik Harjawiyana (2001) maupun Poedjasoedarma (1979) menyebutkan faktor hubungan kekerabatan sebagai latar belakang pemilihan tingkat tutur Krama. Seorang anak akan menggunakan tingkat tutur Krama kepada orang tua dan kakek neneknya, serta sanak saudara yang satu generasi dengan orang tua dan kakek-neneknya. Pengaruh penggunaan ragam Krama oleh anak kepada orang tua, selain untuk penghormatan, juga karena adanya jarak antara mereka. Di zaman sebelum perang dunia kedua biasanya keluarga priyayi mempunyai pengasuh anak atau lebih dikenal dengan sebutan mbok emban (Sinung, 2018). Dari hasil analisis data, ditemukan peristiwa tutur Krama yang dilatarbelakangi faktor hubungan kekerabatan. Berikut di bawah ini adalah contohnya.

\section{Percakapan 20}

\section{$\mathrm{O}_{1}$ : "Nuwun sewu Rama, menapa Rama yakin seratanipun $\mathrm{Ni}$ padha saenipun kaliyan seratan Prabu H adiningrat?"}

'Mohon maaf Rama, apa Rama yakin tulisan Ni sama bagusnya dengan tulisan Prabu Hadiningrat?'

$\mathrm{O}_{2}$ : “Ndhuk, sing arep ngeregani tulisanmu kuwi ya wong liya, malah Rama saiki arep jaluk izin ning kowe, Rama yang akan menerbitkan, piye? Oleh ta?"

'Nak, yang akan menghargai tulisanmu itu orang lain. Bapak sekarang akan minta izin kepadamu. Bapak yang akan menerbitkan? Bagaimana? Boleh kan?'

Dialog pada Percakapan 20 terjadi antara antara Kartini $\left(\mathrm{O}_{1}\right)$ dan ayahnya, RM Adipati Ario Sosroningrat $\left(\mathrm{O}_{2}\right)$. Tuturan pada Percakapan 20 Kartini menggunakan tingkat tutur Krama, sedangkan ayahnyamenggunakan tingkat tutur Ngoko. Dalam peristiwa tutur di atas, sebagai anak, Kartini menempatkan diri dengan benar di hadapan ayahnya dengan memilih tingkat tutur Krama, sedangkan ayahnya memilih tingkat tutur Ngoko untuk merespon tuturan anaknya.Dalam peristiwa tersebut, Kartini menunjukan kesopanan dirinya terhadap ayahnyamelalui penggunaan tingkat tutur Krama. 
Hal tersebut sesusai dengan apa yang dijelaskan oleh Poedjasoedarma (1979) bahwa anak-anak keluarga priyayi pada zaman sebelum proklamasi menggunakan tingkat tutur Krama ketika bertutur dengan orangtua mereka, dan juga terhadap temanteman sepermainan mereka. Namun, pada masa kini tidak sedikit anak yang menggunakan tingkat tutur Ngoko kepada orang tua mereka. Hal itu merupakan akibat perubahan hubungan orang tua - anak. Orang tua masa kini memperlakukan anak seperti teman, demikian pula sebaliknya.

Peristiwa tutur berikut ini memperlihatkan tingkat tutur yang dipilih Kartini $\left(\mathrm{O}_{1}\right)$ saat berbicara dengan ibu tirinya, RA Moerjam $\left(\mathrm{O}_{2}\right)$. RA Moerjam adalah istri sah ayah Kartini (R.M Adipati Ario).

\section{Percakapan 21}

\section{$\mathrm{O}_{1}$ : "Kenging menapa, I bu?" \\ "Ada apa, Ibu?" \\ $\mathrm{O}_{2}$ : "Ora sah perlu ngerti." \\ "Tidak perlu mengerti."}

Kartini menggunakan tingkat tutur Krama saat berbicara dengan ibu tirinya. Sebaliknya, RA Moerjam menggunakan tingkat tutur Ngoko. Pemilihan tingkat tutur tersebut sesuai dengan penjelasan Harjawiyana (2001) dan Poedjasoedarma (1979) tentang faktor hubungan kekerabatan. Akan tetapi, sebenarnya dalam peristiwa tutur tersebut faktor status sosial juga menjadi penentu. Kartini menunjukkan sikap sopan kepada ibu tirinya yang berstatus bangsawan dengan menggunakan tingkat tutur Krama. Kepada ibu kandung yang berstatus sosial lebih rendah, Kartini menggunakan tingkat tutur Ngoko (lihat Percakapan 18).

\section{SIMPULAN DAN SARAN}

Analisis klasifikasi tingkat tutur berdasarkan ciri gramatikalnya dan aspek sosiolinguistik yang dilakukan terhadap film Kartini menghasilkan temuan sebagai berikut. Sebagaimana dijelaskan oleh Maryono Dwiraharjo (dalam Mulyanto, 2015), ciri gramatika yang membedakan tingkat tutur Ngoko dan Krama yang dilihat dari aspek gramatika ditentukan oleh perbedaan kata tugas, pronimona persona, adverbia, demostrativa, pronomina yang menyatakan kepemilikan, numeralia, dan interogativa dan afiks. Hasil penelitian ini memperlihatkan hal yang sama. 
Demikian pula kemungkinan hadirnya kosakata Krama pada tingkat tutur Ngoko dan sebaliknya hadirnya kosakata Ngoko pada tingkat tutur Krama juga sejalan dengan penjelasan peneliti terdahulu. Hal berbeda yang ditemukan di dalam penelitian ini berkaitan dengan jenis kosakata Ngoko yang hadir di dalam tingkat tutur Krama, yang tidak disebutkan oleh Poedjasoedarma (1979) dan Ki Padmususatro (dalam Mulyanto, 2015), yaitu pronomina misalnya $i k u$. Poedjasoedarma (1979) dan Ki Padmususatro (dalam Mulyanto, 2015) mencatat adanya subjenis Krama yaitu Wredhakrama yang mengandung mengizinkan kehadiran afiks Ngoko dan kata-kata seperti sing, kang, mung, ning di dalam kalimat Krama.

Faktor penentu pemilihan tingkat tutur yang ditemukan juga sama dengan yang sudah disebutkan oleh peneliti terdahulu. Hal baru yang dilakukan penelitian ini adalah melihat faktor apa yang lebih menguatkan jika dalam satu peristiwa tutur ada lebih dari satu faktor yang bertolak belakang. Hal itu belum ditangani oleh peneliti sebelumnya. Hasil analisis memperlihatkan bahwa di lingkungan Keraton Jawa pada abad 19, status sosial adalah faktor yang paling memberatkan untuk menentukan penggunaan tingkat tutur. Faktor tersebut mengatasi faktor umur dan hubungan kekerabatan. Hal tersebut memperlihatkan bahwa masyarakat Jawa di kalangan bagsawan lebih mementingkan faktor status sosial dibandingkan faktor lain, misalnya umur dan relasi kekerabatan.

\section{DAFTAR PUSTAKA}

Geertz, C. (1981). Abangan, Santri, Priyayi dalam Masyarakat Jawa. Jakarta: Pustaka Pelajar.

Harjawiyana, H., \& Supriya, T. (2001). Marsudi unggah-ungguh basa Jawa. Penerbit Kanisius. Retrieved from https://books.google.co.id/books?id=nylaupbAwEwC

Muhid, A. (2011). Tingktat Tutur Bahasa Jawa Masyarakat Samin Desa Klopoduwur Kabupaten Blora. Retrieved from http://www.unaki.ac.id/ejournal/index.php/majalah-ilmiahinformatika/article/view/33/64

Mulyanto. (2015). Ki Padmosusastro Membuka Lembaran Sejarah Tingkat Tutur Bahasa Jawa. Yogyakarta: Pustaka Pelajar.

Poedjosoedarmo, S., \& dan Pengembangan Bahasa, P. P. (1979). Tingkat tutur 
bahasa Jawa. Pusat Pembinaan dan Pengembangan Bahasa, Departemen Pendidikan dan Kebudayaan.

Poerwadarminta, W. (1939). Baoesastra Djawa. Groningen: JB Wolters Uitgevers Maatschappij.

Sasangka, S. S. T. W. (2009). Unggah-Ungguh Bahasa Jawa. Jakarta: Yayasan Paramalingua.

Scollon, R., \& Scollon, S. W. (2001). Intercultural Communication: A Discourse Approach. UK: Basil Blackwell Ltd.

Sinung, W. (2018). Dinamika Kehidupan Priyayi Jawa Abad 19-20 Dalam Novel Tetrologi Pulau Buru Karya Pramoedya Ananta Toer: Sebuah Studi Komparasi Realitas Historis. Avatara, 6. Retrieved from http://jurnalmahasiswa.unesa.ac.id/index.php/avatara/article/view/26464

Sudaryanto. (2015). Metode Dan Aneka Teknik Analisis Bahasa: Pengantar Penelitian Wahana Kebudayaan Secara Linguistis. Yogyakarta: Sanata Dharma University Press.

Wajdi, M. (2013). Sistem Kesantunan Masyarakat Tutur Jawa. Retrieved from https://ojs.unud.ac.id/index.php/linguistika/article/view/9706

Wedhawati, \& Dkk. (2006). Tata Bahasa Jawa Mutakhir. Yogyakarta: Kanisius.

Wijayana, I. D. P., \& Rohmadi, M. (2013). Sosiolinguistik: Kajian Teori dan Analisis. Yogyakarta: Pustaka Pelajar. 